Portland State University

PDXScholar

\title{
A Race to the Finish: an Analysis of Factors Contributing to the Achievement Gap in Portland Public School District
}

Victoria Noggle

Portland State University

Follow this and additional works at: https://pdxscholar.library.pdx.edu/honorstheses

Let us know how access to this document benefits you.

\section{Recommended Citation}

Noggle, Victoria, "A Race to the Finish: an Analysis of Factors Contributing to the Achievement Gap in Portland Public School District" (2014). University Honors Theses. Paper 90.

https://doi.org/10.15760/honors.101

This Thesis is brought to you for free and open access. It has been accepted for inclusion in University Honors Theses by an authorized administrator of PDXScholar. Please contact us if we can make this document more accessible: pdxscholar@pdx.edu. 
A Race to the Finish: An Analysis of Factors Contributing to the Achievement Gap in Portland Public School District

\author{
by
}

Victoria Noggle

An undergraduate honors thesis submitted in partial
fulfillment of the
requirements for the degree of
Bachelor of Science
in
University Honors
and
Child and Family Studies

Thesis Advisor

Ben Anderson-Nathe

Portland State University 


\begin{abstract}
$\underline{\text { Abstract }}$
Closing the achievement gap is one of the most talked about issues within the United States education system. The achievement gap refers to disproportionality in rates of achievement between white students and students of color. The question should not be how one closes the achievement gap but what factors contribute to the achievement gap and how these factors can be addressed. This paper looks at the achievement gap between white and black students on a national level, focusing on research addressing different factors pertaining to the gap. Five main factors contribute to the achievement gap between white and black students: neighborhood segregation, socioeconomic status, parent influence, school discipline and standardized testing. This thesis considers the role of each factor as it pertains to Portland Public School District's racial achievement gap as evidenced by high school graduation rates, test scores, and dropout rates.
\end{abstract}




\section{$\underline{\text { Introduction }}$}

"In the field of public education, the doctrine of 'separate but equal' has no place. Separate educational facilities are inherently unequal." These words were spoken 60 years ago by Chief Justice Warren during Brown v. Board of Education. Although white students and students of color are able to attend the same educational facilities, sixty years later education is still not equal. According to the National Center for Education Statistics (NCES), the national high school graduation rate for 2010 was 78 percent. White students had a graduation rate of 83.0\%, while the graduation rate for African American students was 66.1\%. The dropout rate for Hispanic and African American students was more than double the national average. This gap in achievement has shown up on the National Assessment of Education Progress and on state and local tests, in rates of graduation, dropping out, suspension, expulsion, and assignment to education (Carter \& Welner, 2013). Most studies determine the achievement gap based on national-average test-score differences between racial and ethnic groups based on the NAEP and SAT results (Lee, 2002; Billings, 2006; Reardon et al., 2013). This analysis includes the differences in standardized test scores and the graduation and dropout rates between black and white students in terms of achievement.

Researchers have paid attention to many of the different factors that may contribute to the achievement gap. Lee (2002) suggests that socioeconomic and family conditions (educational attainment, income, poverty, single household): youth culture and student behavior (motivation and effort for learning, alcohol and illicit drug use, crime); and schooling conditions and practices (instructional resources, teachers, course taking, dropout, segregation) are some of the factors behind achievement gaps. Billings (2006) suggests that the composition of a school, the students' sense of control of the environments, the teachers' skills, and the students' family 
background. Not one factor can be attributed to the cause of the achievement gap and in fact most of the factors studied by other researchers are all intertwined with race. My research demonstrates that the main factors are neighborhood segregation, socioeconomic status, parental influence, school discipline/teacher involvement and standardized tests. In the following sections, I describe how the five factors individually affect the achievement gap nationally between black and white students.

\section{Neighborhood Segregation}

Card and Rothstein's (2006) research provides evidence that the achievement gap between black and white students is higher in more segregated cities. The research suggests that when looking at the scores within a highly segregated city and shifting into an integrated city, the gap narrows. The research also suggested that neighborhood segregation seemed to matter more than school segregation. These researchers consistently found a strong correlation between neighborhood segregation and lower scores, whereas the effects of school segregation were not statistically significant. When considered separately however, both school and neighborhood segregation have negative effects on black achievement, thus adding to the national achievement gap between black and white students. Diamond (2006) takes this a step further by drawing on a case study that reveals how even in integrated suburbs, black and white students take different paths that lead to an educational advantage for white students.

Diamond's article discusses the case of Lakeside school, a large and impressive looking school with a student population of 3,000 students. The student body was made up of $48 \%$ White, $40 \%$ Black, seven percent Hispanic, and two percent Asian. Although the school had impressive academic accomplishments, there were still had significant racial gaps. According to 
the school's data, African American students had lower GPAs, did not perform as well on standardized tests, and were less likely to be enrolled in honors classes. Students of color made up more than $50 \%$ of the school population but only 20 students of these students ranked among the top 100 students in 2001 and $75 \%$ of the failing grades that year were given to students of color. Lakeside belonged to the Minority Student Achievement Network (MSAN), a national organization of suburban school district focused on addressing racial gaps in achievement. MSAN research showed that $50 \%$ of White students belonging to MSAN school districts reported GPAs of A or A-, while only $15 \%$ of African American students were in this range. Conversely, 44\% of African American students reported a GPA of C+ or lower, while only $14 \%$ of Whites reported grades in the below average range. Diamond states that although better than segregated schools, integrated schools have still failed to create equal opportunity for all students. Card and Rothstein's research and Diamond's study provides insight that neighborhood segregation does not contribute to the academic achievement alone but is a contributing factor to the gap, producing evidence that although the gap is existent in integrated schools, it appears at a higher rate within segregated cities.

\section{Socioeconomic Status}

Researchers have examined socioeconomic status as a determinate in the achievement gap, however wealth is often not included in conceptualizations of this factor (normally income, educational attainment, and occupational prestige are viewed as the sufficient indicators of the socioeconomic factor. Orr (2003) argues that wealth is not only a determinant of achievement but adds to the test score achievement gap between black and white students. Orr's theory is that wealth is a form of economic capital that can be "cashed in" for other forms of capital, such as 
social or cultural). Wealth as an economic capital can allow parents to purchase educational resources for their children such as books, computers, private schooling, and raise their status symbol in school. Research has shown that many black students come from families with lower levels of wealth, meaning these children have less access to financial, human, cultural, and social capital. With lower levels of financial capital, these students have less access to the resources listed above. Having restricted access to these resources provides them with a lower cultural capital, overall lowering their human capital and academic achievement. Because black and white families differ in the amount of wealth and financial capital they possess, wealth can explain the overall achievement gap between black and white students.

The socioeconomic status of a student does not start as they enter high school; instead the child's socioeconomic status can have an effect on the achievement gap before the child even enters the K-12 system. Duncan and Magnuson (2005) produced an article considering whether the SES of families affects the school readiness among preschoolers. The data concluded the average SES of black kindergarteners was more than two-thirds of a standard deviation below that of white students. The study found that on average, black students' academic skills lag behind their white peers. Due to having higher chances of coming from a low socioeconomic family, black students are more likely not to attend preschool (unless enrolled in a Head Start program). This lack in early childhood education, can lead to students being behind when entering the K-12 education system, thus adding to the achievement gap before even entering school. 


\section{Parental Influence}

In the American society, the idea of parental involvement benefitting students in the classroom has been so appealing, that many educators and researchers have considered parental involvement an important factor in achievement. Fan and Chen (2001) conducted a metaanalysis to combine the quantitative literature on the relationship between parental involvement and student achievement. Through this study, they followed three age cohorts based on grade level of child in order to see if/how parental influence changes over time. The research found that there was a 12 point standard deviation between black and white children's achievement. The research found that when looking at family background, the grandparents of black children have lower educational attainment than that of white children's grandparents. About $40 \%$ of white children had a maternal grandparent with some form of higher education; fewer than $15 \%$ of black children have a grandparent with a similar educational background. Looking at the mother's background, research shows that $14 \%$ of black mothers were under the age of 20 , and $31 \%$ were receiving welfare. This compares to four percent and five percent of white mothers respectively. Black children are also significantly more likely to live in a household with a single mother or a large family at $60 \%$ compared to white children at $14 \%$. It is also shown that white children are more likely to live with both parents present (82\%) compared to $33 \%$ of black students.

\section{School Discipline}

While many researchers have focused on achievement gaps based on academic performance, how the disproportionate suspension and expulsion rates may play into the achievement gap has received less attention. Gregory, Skiba, and Noguera (2010) present the 
notion that schools tend to rely heavily on exclusion from the classroom as the main disciplinary strategy, and the practice of doing so has a disproportionate impact of students of color. The use of this exclusion technique as a discipline practice may contribute to the racial gaps in achievement. The Children's Defense Fund first brought discipline disproportionality to national attention, when showing that black students were two to three times more likely to be suspended than their white peers. In 2003 almost one in five black students were suspended compared to the fewer than one in ten white students. According to Gregory et al. (2010) a nationally representative survey of 74,000 tenth graders found that 50 percent of black students reported having ever been expelled compared with about 20 percent of white students. In many schools, large proportions of students receive at least one suspension, typically resulting in missed instructional time, which could lead to academic failure and disengagement. The disciplinary practice used most widely throughout the United States is the principal's office or throw out method, causing students to miss valuable class time. This missed time may contribute to lowered academic performance among students in the greatest need for improvement. Arcia (2006) followed two demographically similar cohorts, comparing the variable of at least one suspension to no suspensions. Within a year, suspended students were already three grade levels behind their nonsuspended peers in reading skills. Two years later the cohort that had been suspended was almost five years behind their nonsuspended peers.

Studies of the relationship between achievement and student discipline have shown that when taking grade point average into account, race remains a predictor of academic suspension (Gregory et al., 2010). Kinsler (2013) poses the question whether variation in discipline policy has any effect on the achievement gap. Research showed that suspended students were significantly more likely to be male, retained, disabled, and coming from households with lower 
educational attainment. When this discipline was changed in terms of the teachers' perspective on the discipline gap, the rates of these students lowered. Overall there needs to be a change in the way discipline is addressed and how teachers need to address students of a different culture than their own.

\section{Standardized Tests}

As mentioned earlier, standardized tests have become a major way in which the achievement gap is measured across the nation, but do these tests actually have an effect on the achievement gap itself? According to Steele and Aronson (1995) the stereotype threat causes many students to perform lower on standardized tests. In researching SAT differences between black and white college students, Black participants performed worse than White participants when tests were presented as a means of measuring ability. If the student perceives that a significant portion of the test is within their capability, they may be able to surpass the stereotype threat. When a student does not have this perception of themselves, the group stereotype becomes relevant as an explanation and undermines performance (Steele \& Aronson, 1995). This stereotype threat causes many students to lose their potential and feel that they are just another statistic. This sense of thinking comes with state standardized tests and puts more pressure on students of color than their white counterparts. The factor of standardized tests along with the others mentioned in this thesis are all intertwined in the city of Portland, Oregon and contribute to the achievement gap within the Portland Public School District. 


\section{Background of Multnomah County}

Oregon has had a long and troubled racial history. In 1844 laws were passed to not only ban slavery from the state but also all Blacks. Five years later another law was passed prohibiting entrance to African Americans; this was overturned by the passage of the $14^{\text {th }}$ Amendment. During this time many African Americans traveled to the Portland area to work on railroads and as domestic servants (Bates, Curry-Stevens, \& Coalition of Communities of Color, 2014). After the release of the 2010 census data, research was conducted by Nikole Hannah-Jones of the Oregonian, showing that Northeast Portland had become significantly whiter. In 2000, there were ten tracts in the Albina neighborhood that were predominately black; in 2010, there were nearly none due to a massive move out of black residents (Bates, Curry-Stevens, \& Coalition of Communities of Color, 2014). Hannah-Jones discussed what happened to those displaced residents:

“...those who left didn't move to nicer areas. Pushed out by gentrification, most settled on the city's eastern edges, according to the census data, where the sidewalks, grocery stores, and parks grow sparse, and access to public transit is limited. As a result, the part of Portland famous for its livability - for charming shops and easy transit, walkable streets and abundant bike paths - increasingly belongs to affluent whites. (Bates, CurryStevens, \& Coalition of Communities of Color, 2014)."

The Coalition for Communities of Color in Multnomah County put together a report discussing the challenges that people of color face in the county. Some of the data includes that $50 \%$ of black (African American) children are under the poverty line compared to $13 \%$ of white children. More than half of youth identifying as African American do not graduate high school compared to a third of their white peers. Black students are much more likely to be disciplined (more than double) (Bates, Curry-Stevens, \& Coalition of Communities of Color, 2014). According to the data accumulated, the median income of an African American working full time is $\$ 36,483$, compared to the white coworker making $\$ 45,353$ in Multnomah County. This 
income gap has remained constant over the last 20 years, giving blacks a higher disadvantage as inflation continues to occur. Figure 1 below depicts income by race for Multnomah compared to nationwide, showing that income disparities are worse locally than with national averages.

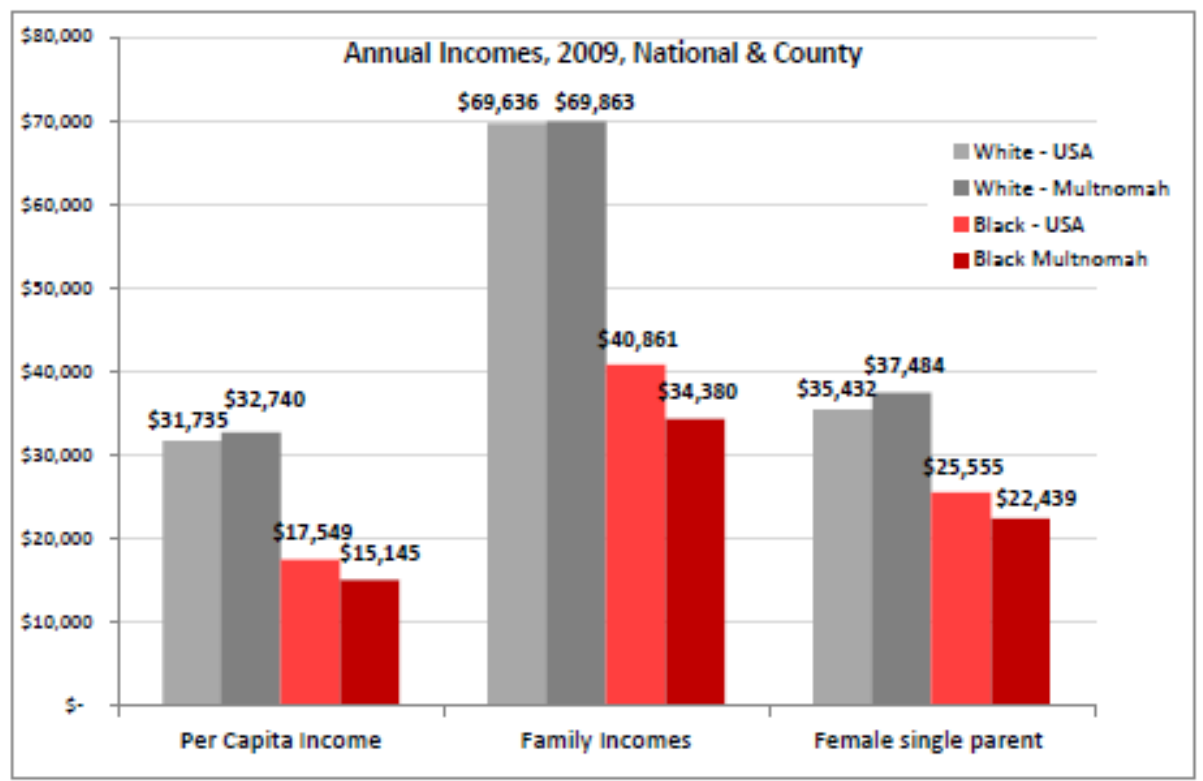

Source: Multnomah Coalition for Communities of Color.

For every three black residents in Multnomah County, one of them is living in poverty, while one in every eight white residents face this issue. $27 \%$ of black families are living below the poverty line, compared to the $7 \%$ of white families. African American single mothers with school aged children have a two-in-five chance of living in poverty, if the child is under the age of five this raises to a three-in-five chance (Bates, Curry-Stevens, \& Coalition of Communities of Color, 2014). Overall these socioeconomic disparities are affecting black families in more than just terms of money but also in housing and education for their children in Multnomah County.

In 2010, $17 \%$ of black adults had not yet completed high school in Multnomah County, while only $6 \%$ of white adults had yet to finish their general education degree. $43 \%$ of white adults in Multnomah County have a post-secondary degree (college or graduate/professional), while only $14 \%$ of blacks have a bachelors, and $21 \%$ have a college or graduate/professional 
degree at all. Figure 2 below shows the educational attainment for adults in Multnomah County comparing black and white residents.

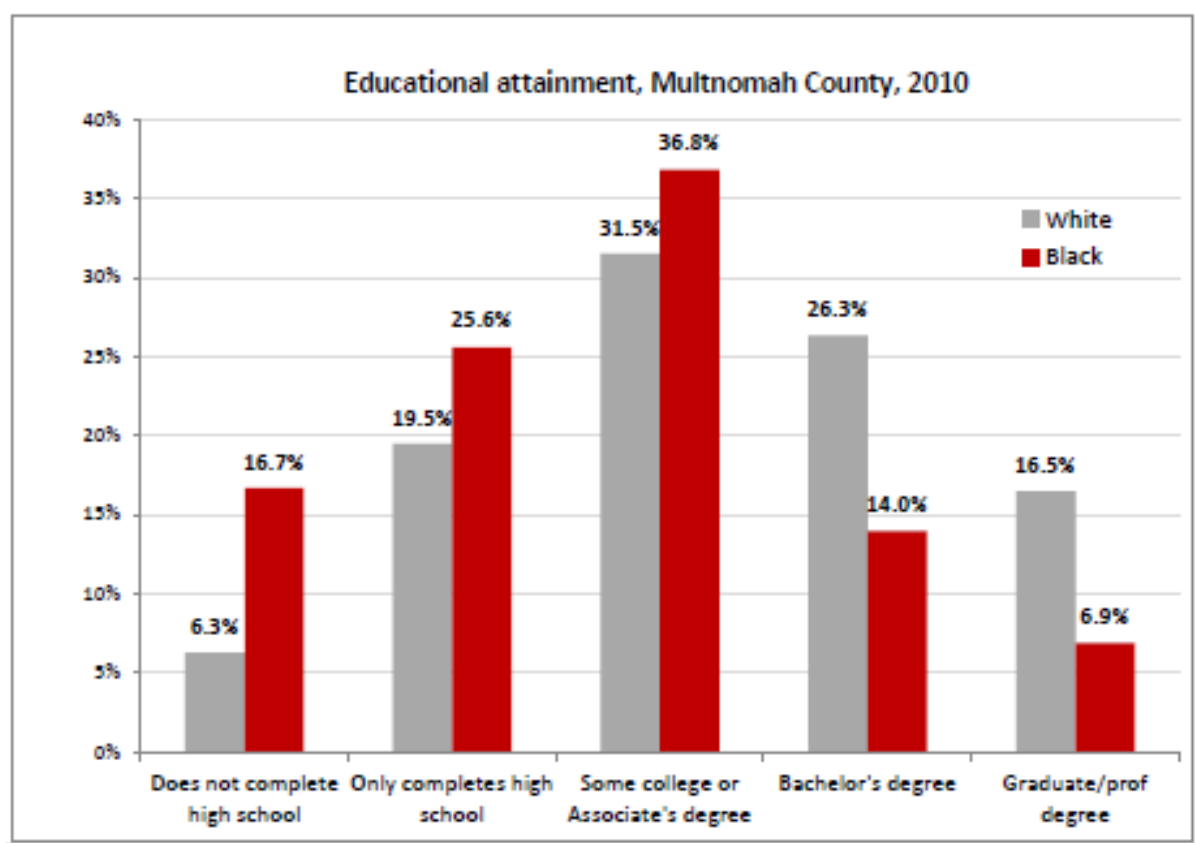

Source: Multnomah Coalition for Communities of Color.

In order to obtain economic mobility within current day society, one must obtain a high school diploma. Most would think that black students aren't achieving as well due to the higher levels of poverty, however there would be an expectation that higher income black students would achieve reaching a high school diploma at the same rate as their white middle class peers. The graduation rate for blacks however, is nearly equal across socioeconomic status compared to that of white peers, in which having a higher socioeconomic status increases the graduation rate by ten percent (Bates, Curry-Stevens, \& Coalition of Communities of Color, 2014). Figure 3 shows the graduation rates for Multnomah County over a four year span for both black and white students. Showing, on average a growth in graduation from white students, however a decrease in graduation from 2011-2012 in black students. 


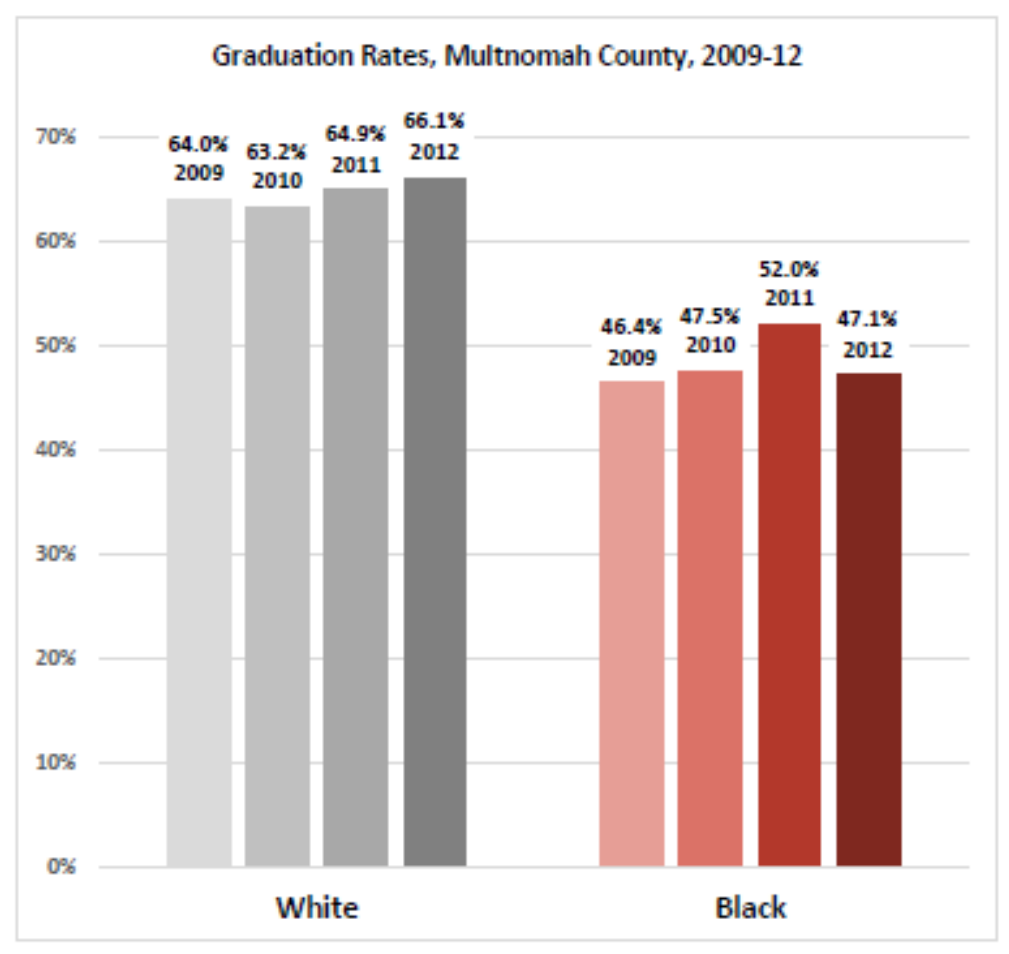

Source: Multnomah Coalition for Communities of Color.

One of the main causes of low graduation rates is high percentages of school expulsion and suspension. Within Multnomah County, the rate of expulsion and suspension has gone both up and down over the years, but has constantly stayed at a higher rate for African American students than their white counterparts. This is interesting considering that researchers have not found evidence as to why these students are getting removed from the classroom at such alarming rates. Figure 4 shows the percentage of students expelled or suspended over a five year period for black and white students. Rates of discipline have risen higher and faster for black students than any other population of student in Multnomah County (Bates, Curry-Stevens, \& Coalition of Communities of Color, 2014). 


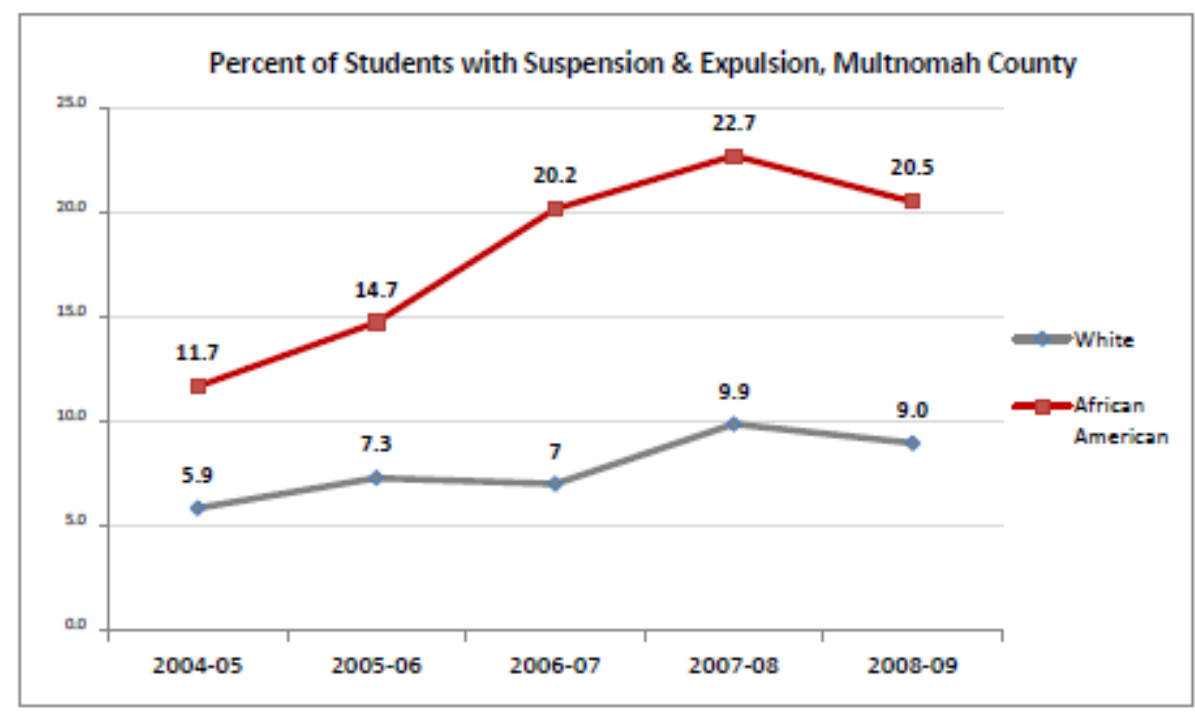

Source: Multnomah Coalition for Communities of Color.

All of these issues have been looked at through the county level, showing that there are significant differences between black and white students within the education system, and within their families outside of it. What does this look like at a Portland based level? Does Portland Public Schools look any different?

\section{Background of Portland}

Portland is the largest metropolitan area in Oregon, located approximately 90 miles from the Pacific Ocean. In 2000, the population was 1,918,009 in the entirety of the Portland Primary Metropolitan Statistical Area. According to Gibson and Abbott (2002), Portland alone contained 536,240 residents in 2000. The population of Portland is separated into west and east, and with that comes the separation of types of people. The west side generally has a higher average level of educational attainment, a higher number of professional and managerial workers, and a higher income. The African American population remains the most congregated in older neighborhoods located on the north and northeast side of Portland. Although black populations were able to 
move into the suburbs starting in the 1980s, $73 \%$ of the African Americans in the census region still live in Multnomah County (Gibson \& Abbott, 2002). Figure 5 represents the population of Portland based on race using data from the 2000 census as portrayed by Eric Fischer. Red represents White, blue is the Black population, green is Asian, orange is Hispanic, and yellow is other. Each dot represents 25 residents.

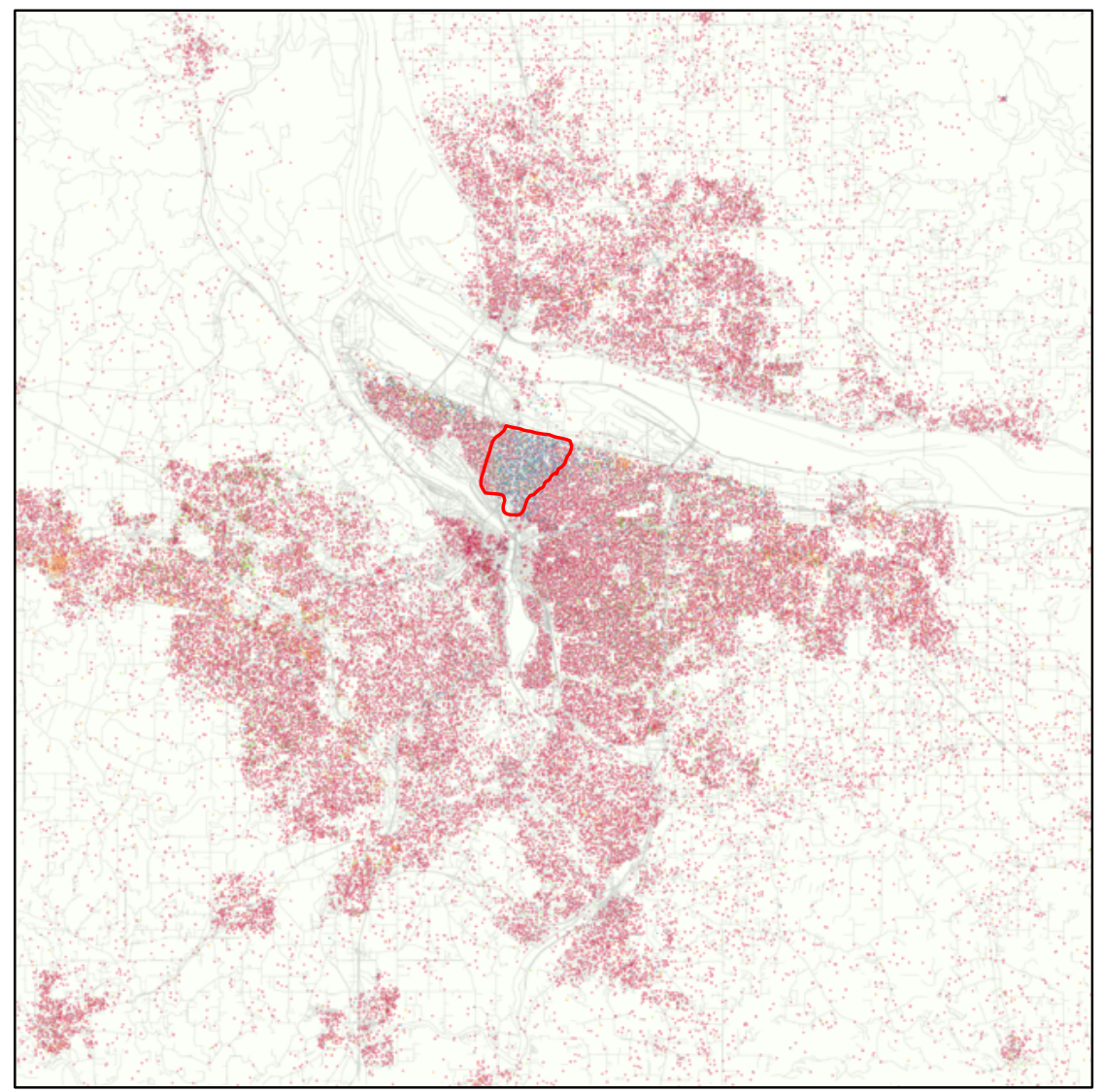

Source: Eric Fischer's Flickr Photo Stream

As one can see from Figure 5, Portland is mostly white; however there are some patches of color. The black population predominately resides on the northeast side as represented by the blue patch of dots in the center of the map. Not only is this region predominately populated by black residents but it is also one of the lower income communities in Portland. Figure 6 below shows the poverty rates according to the 2000 census. The colors represent different percentages 
of the population below the poverty line. The lightest represents $0-6 \%$, followed by $7-12 \%, 13$ $23 \%$, and $24-57 \%$.

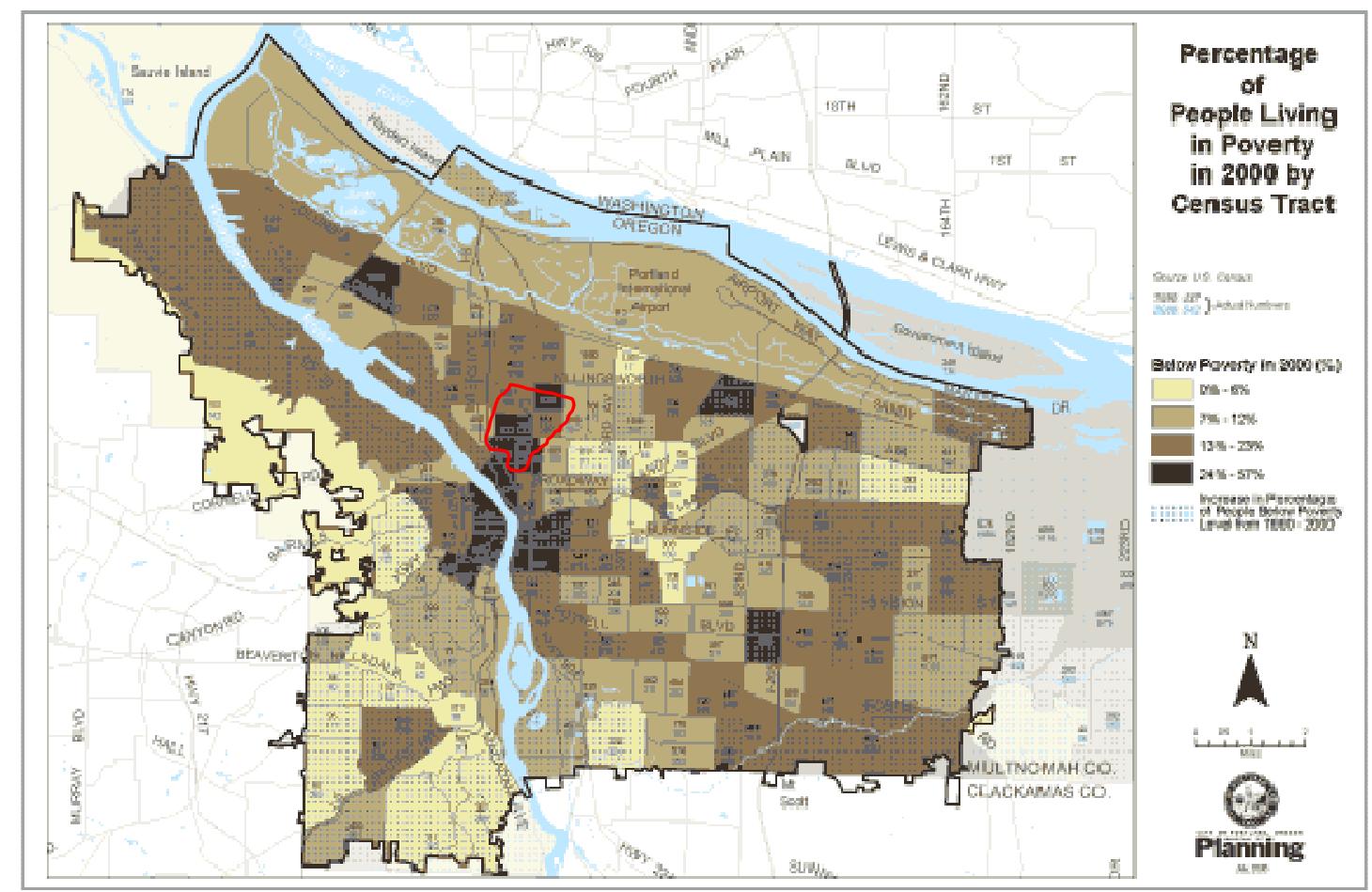

Source: The City of Portland Planning and Sustainability Operations Team

Comparing Figure 5 and Figure 6, one can see that the area where black residents predominately reside, there are also higher levels of poverty (represented by the red outline). Not only does this show how neighborhood segregation and socioeconomic intertwine, but also infers that black families are making much more than white families, creating larger challenges for their children to face in education.

This economic struggle is nothing new for African Americans. High unemployment rates have been a condition for African American community for over 50 years, meaning that many families are experiencing multiple generations of unemployed adults. Currently African Americans are facing higher unemployment rates and longer stretches of being unemployed, widening the income gap between black and white residents in the Portland neighborhood. Table 
1 below shows the unemployment rate overtime, this compares the Portland and the United States unemployment rates as well as the difference between unemployment rates for black and white citizens.

\begin{tabular}{|c|c|c|c|c|c|c|}
\hline \multicolumn{6}{|c|}{ Unemployment Rates \& Black-White Ratios, Portland and United States, 1970-2006 } \\
\hline & \multicolumn{7}{|c|}{ Portland } & \multicolumn{3}{c|}{ United States } \\
\hline Males & White & Black & B/W Ratio & White & Black & B/W Ratio \\
\hline 1970 & $7.4 \%$ & $11.9 \%$ & $\mathbf{1 . 6}$ & $3.6 \%$ & $6.3 \%$ & 1.8 \\
\hline $\mathbf{1 9 8 0}$ & $6.2 \%$ & $15.2 \%$ & $\mathbf{2 . 5}$ & $5.9 \%$ & $12.3 \%$ & $\mathbf{2 . 1}$ \\
\hline $\mathbf{1 9 9 0}$ & $5.9 \%$ & $15.0 \%$ & $\mathbf{2 . 5}$ & $5.3 \%$ & $13.7 \%$ & $\mathbf{2 . 6}$ \\
\hline $\mathbf{2 0 0 0}$ & $6.6 \%$ & $15.6 \%$ & $\mathbf{2 . 4}$ & $4.4 \%$ & $12.3 \%$ & $\mathbf{2 . 8}$ \\
\hline $\mathbf{2 0 0 6}$ & $6.2 \%$ & $16.6 \%$ & $\mathbf{2 . 7}$ & $5.0 \%$ & $13.4 \%$ & $\mathbf{2 . 7}$ \\
\hline Females & & & & & \\
\hline $\mathbf{1 9 7 0}$ & $5.4 \%$ & $8.1 \%$ & $\mathbf{1 . 5}$ & $4.8 \%$ & $7.7 \%$ & 1.6 \\
\hline $\mathbf{1 9 8 0}$ & $5.1 \%$ & $13.4 \%$ & $\mathbf{2 . 6}$ & $5.7 \%$ & $11.3 \%$ & $\mathbf{2 . 0}$ \\
\hline $\mathbf{1 9 9 0}$ & $5.2 \%$ & $10.6 \%$ & $\mathbf{2 . 1}$ & $5.0 \%$ & $12.2 \%$ & $\mathbf{2 . 4}$ \\
\hline $\mathbf{2 0 0 0}$ & $4.9 \%$ & $11.5 \%$ & $\mathbf{2 . 4}$ & $4.3 \%$ & $10.9 \%$ & $\mathbf{2 . 6}$ \\
\hline $\mathbf{2 0 0 6}$ & $4.8 \%$ & $10.4 \%$ & $\mathbf{2 . 2}$ & $5.1 \%$ & $11.9 \%$ & $\mathbf{2 . 3}$ \\
\hline
\end{tabular}

Source: Multnomah Coalition for Communities of Color.

Because of such high poverty rates, many parents are unable to provide their child with the resources they need in order to do well in school. This then is up to our schools to provide students with supports and materials in which they can utilize to achieve greatness; however currently the Portland Public School District is falling behind in this aspect.

Issues within the Portland Public School District

Although Portland Public School (PPS) District serves a majority of Portland's youth, there have been major issues within the educational system. These issues include unsatisfactory rates of achievement for students, persistent achievement gaps for students of color and students 
of low socioeconomic status (Resolution 4236). These issues have been supported by seven different statistics in the 2008-2009 school years, including on track to graduate, achievement gap, graduation rates, variable graduation rates by school, ACT scores, students perceptions of college, and college persistence and entry rates.

On Track to Graduate: According to Resolution 4236, 63\% of white students and 35\% of African American students were considered on track to graduate by $9^{\text {th }}$ grade. This not only leads into the argument of an achievement gap, but also shows that PPS is not serving minority students effectively.

Achievement Gap: There is a 20 to 50 percentage point gap between white students and the lowest performing students of color in terms of graduation rates, $10^{\text {th }}$ grade benchmarks and core credit completion in $10^{\text {th }}$ grade, and ACT test scores.

Graduation Rates: In combining minority and white students, the graduation rate is only between $53.6 \%$ and $68.6 \%$.

Variable Graduation Rates: If each high school is looked at by itself, the graduation rate ranges from $42 \%$ to $89 \%$ using the Oregon Department of Education Cohort Rate.

ACT Scores: $55 \%$ of juniors attending PPS scored ready in English, 47\% in Reading, 39\% in Math, and 26\% in Science. Only 25\% of seniors were college ready in three of four areas of the test. This is way below where the rate should be, as according to the district's milestones, state students should score college ready in at least three of four areas by their senior year. 
Student Perceptions of College: According to a senior survey in 2008, 54.7\% of senior students attending a Portland Public High School stated that they planned on attending college after graduation. In actuality, the highest college entry rate has been $43 \%$ while the lowest was $36.8 \%$.

College Persistence and Entry Rates: Only about 27\% of all PPS graduates go on to complete a four year university degree within six years. $62 \%$ of graduates enter some form of college ( 2 or 4 year) within a year of graduation.

The above information from Resolution 4236 (2010) only mentioned race in a few of the statistics and shows that Portland Public School District is not only behind in serving the students of color but also white students as well. This means that students of color are even more likely to fall behind, especially African American students. Figure 4 shows the cohort graduation rates for 2011 within the different Multnomah County school districts. This chart shows that Portland Public School District performed the second worse in graduating their black students.

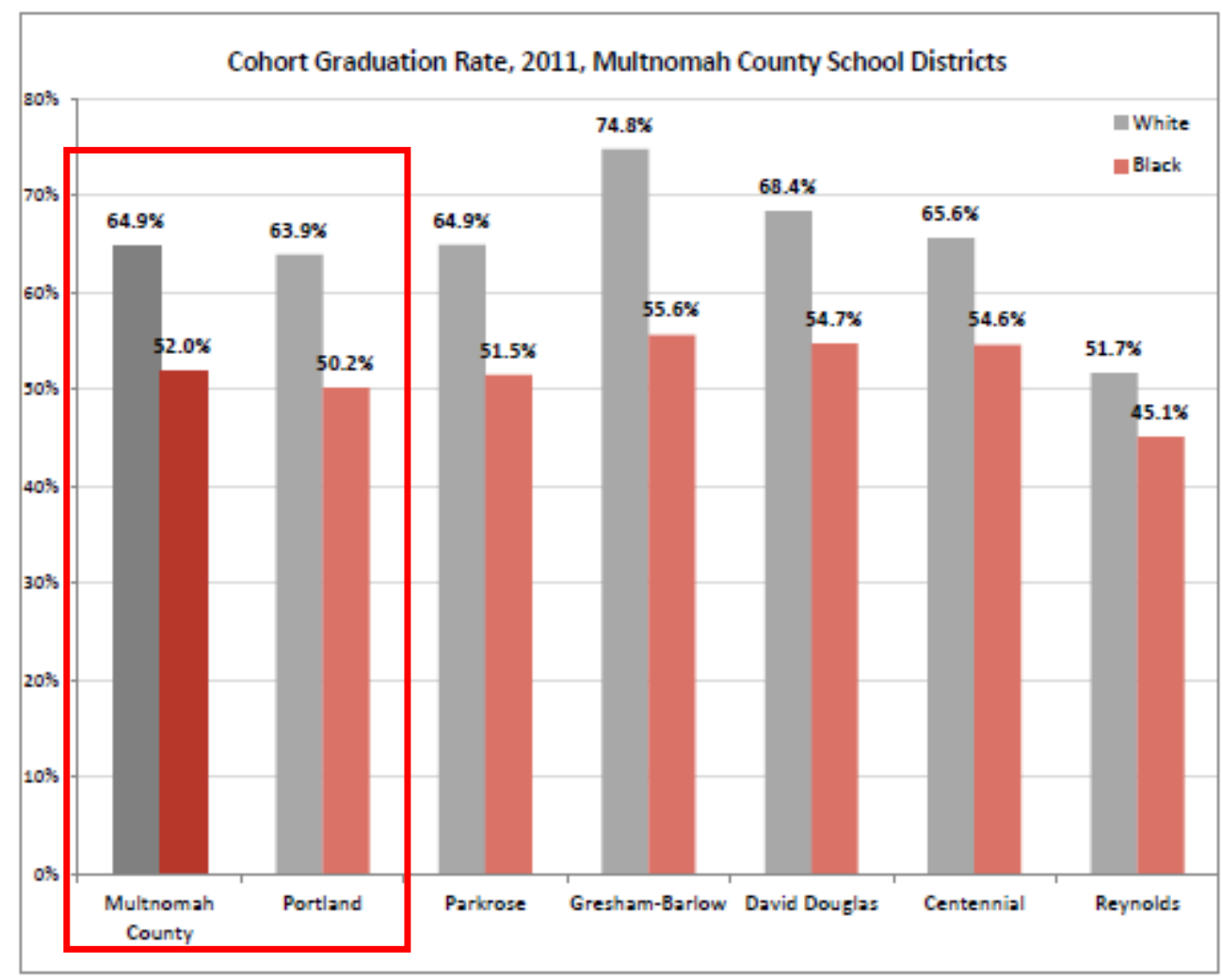


As stated before with a decrease in graduation rate, an increase in the rate of discipline of the students follows. Figure 8 shows the relative rate index for which black students are suspended or expelled compared to the white students within the same school. Portland Public School

District once again has the second highest with a rate of about three and a half to one.

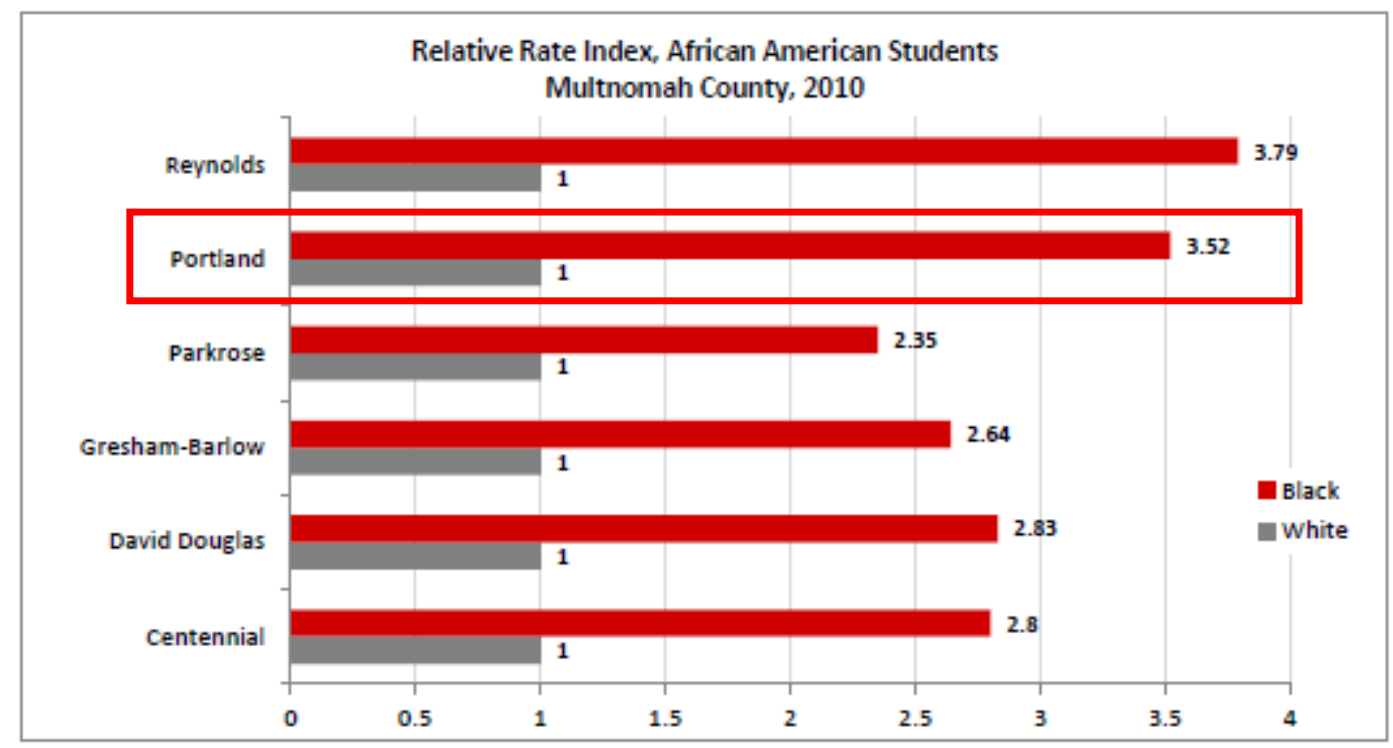

Source: Multnomah Coalition for Communities of Color.

With the increase in school discipline, comes the decrease of classroom time. A lower amount of classroom time means the student is retaining less information, and will ultimately do worse on their standardized testing. Figure 9 is a portion of the Portland Public School District 2010-2011 report card. Highlighted is the fact that 39\%, 63\%, 62\% of black students within Portland Public Schools did not meet the state standards in language arts, mathematics, and science respectively, compared to $11 \%, 23 \%$, and $17 \%$ of white students. 


\begin{tabular}{|l|c|c|c|c|c|c|c|c|c|}
\hline STUDENT GROUP & \multicolumn{3}{|c|}{ STUDENT ACHIEVEMENT } \\
\hline \multirow{2}{*}{ Race/Ethnicity } & \multicolumn{3}{|c|}{ ENGLISHI } & \multicolumn{3}{c|}{ MATHEMATICS } & \multicolumn{3}{c|}{ SCIENCE } \\
\hline American Indian/Alaskan Native & 22.3 & 47.9 & 29.8 & 16.1 & 35.4 & 48.5 & 12.1 & 41.7 & 46.2 \\
\hline Asian/Pacific Islander & 33.4 & 47.1 & 19.5 & 36.2 & 37.1 & 26.7 & 20.9 & 44.4 & 34.7 \\
\hline Black (not of Hispanic orioin) & 12.7 & 48.2 & 39.1 & 7.9 & 28.6 & 63.5 & 4.7 & 33.3 & 62.0 \\
\hline Hispanic & 17.5 & 46.9 & 35.6 & 13.3 & 33.4 & 53.3 & 8.3 & 38.6 & 53.0 \\
\hline White (not of Hispanic orioin) & 51.7 & 37.3 & 11.0 & 38.5 & 37.6 & 23.9 & 36.6 & 46.0 & 17.5 \\
\hline \hline Multi-Racial/Multi-Ethnic & 44.4 & 40.4 & 15.2 & 34.3 & 35.8 & 30.0 & 29.6 & 48.8 & 21.6 \\
\hline
\end{tabular}

Source: Portland Public School District

With these major issues affecting all of the students at Portland Public School but specifically

the black students, why hasn't something been changed? What can/should be changed? Is there a way to start creating equity within the Portland Public School District, giving equal opportunities to the African American students within the classroom?

Implementations of Change

The biggest concern facing the children of today is whether they will receive an equitable education no matter where they are attending school. As of right now the Portland Public School District is trying to strive towards this goal, however certain factors have to be addressed in the school setting that are causing schools to fail. Neighborhood segregation, socioeconomic status, parental influence, school discipline/teacher involvement, and standardized testing need to be addressed within the classroom and not used as excuses to why administration can't fully address the achievement gap.

\section{Addressing Neighborhood Segregation}

Most would be unsure how to address this issue within a school setting; however the main occurrence with neighborhood segregation is that many of the low income and failing 
schools are in areas highly populated by people of color. Due to No Child Left Behind, students are given a free pass to transfer out of a failing school into a passing one. This is the case for schools in Portland, specifically Jefferson High School located between Alberta and

Killingsworth. Students in the neighborhood that feel they need to succeed in their education will often transfer out of Jefferson because they don't want to have a college see that they came from a failing high school. When the student transfers the money that pays for the student goes with them. This means that the non-failing schools are actually taking money from the schools that are failing, causing them to continue to fail due to not having the proper resources for their students. To keep the funding within the school, transfers should be eliminated. Most would say this isn't fair to students who want to achieve, however if transfers are eliminated more money and resources can be implemented into the school. If there is a necessity for transfers, than money should not transfer with the child, but stay in the neighborhood school that the child should be attending.

\section{Combatting Socioeconomic Status}

Many students that come into the classroom from a low SES family often do not have the supports they need in order to succeed within the classroom. While many middleclass children are enrolled in summer camps to harness and retain information from the classroom, children facing poverty do not often receive this luxury. Many of these students don't even have the supplies at home that one might find in a classroom, such as books, coloring utensils, calculators, etc. For this reason there needs to be investments in school supports that youth need to excel academically. This would entail providing text and computer accessibility to students that are unable to access this at home. Faculty need to invest in afterschool programs and even summer 
supports that promote positive development that some families may not be able to provide. In order to start combating socioeconomic status within the classroom, one has to offer both the child and the family the supports they need, that they may not receive otherwise.

\section{Increasing Parental Involvement}

Being a parent in a low SES household is difficult, especially if you are a single parent. Many of the hours are spent balancing three jobs just for basic needs, barely leaving time for picking up kids, making dinner, or interacting with the child's teacher. Parent communication and involvement is important for any child's education, but sometimes parents are unable to attend meetings due to work schedules and other commitments they need to provide. For this reason, meetings need to be structured around the parent schedule. If needed teachers should ask parents if there is a better location that is more accessible to the school. Going to the parent allows for room to communicate and collaborate about the child, not creating a power dynamic or sense of shame in the parent when they cannot attend a meeting. Parents also need to be kept in communication when their student is well-behaved, not just when the child is having behavioral issues. A weekly status of the child should be communicated with the parent, allowing them to hear what is going on in the classroom and once again keeping the parent in the loop as to how their child is participating in class, and what that parent may need to do at home to push the child further to success.

\section{Counteracting School Discipline}

School discipline has mainly been seen in the form of referrals, suspension, and other forms of removal from the classroom. Many of the students learn that they can get out of 
learning or doing the work when this occurs because they may not have someone monitoring them. The removal from the classroom is detrimental in both the student's education and the relationship between students and teachers. At times behavior may get to the point where suspension or removal from the classroom is needed; however faculty should utilize the inschool suspension method. Using this method would include providing meaningful engagement and supports for the child. These supports need to be both academic and problem-solving skills to help the student learn coping skills with the disruptive behavior. Teachers need to be given training to work with students of different backgrounds, giving them experience with how to handle students that are culturally different from themselves. Teachers also need to be aware of a cultural bias that may occur in their classroom. They need to review each month the list of students they referred to administration, keeping track of the ration of black to white students they are writing up and the reasoning for each write up. Teachers and administration have to be held accountable for disparities of suspension and expulsion, monitor for bias, and be provided with training in alternatives to exclusionary methods.

\section{Changing Standardized Testing}

Standardized testing has not only been shaped by a stereotype threat, but has also created a way for teachers to be evaluated. Many teachers are forced to teach to the test, meaning they are evaluated on how well students perform and how many students pass the standardized exams. Teachers have to stick to a strict curriculum and many move on before students even have a chance to grasp what they are doing. If teachers do not get their numbers within the passing range, they not only are blamed for contributing to a failing school but some are cut from their position. This is due to the lack of funding the school receives because of those failing scores 
being blamed on the teacher. For these reasons standardized testing needs to be eliminated as a way to evaluate teachers. Instead of how well their students do on a standardized test, they will be graded on the improvement of their students through grades, unit testing, and end of the year evaluations. At the beginning of each unit teachers will make a goal statement. This statement addresses what they plan to accomplish in the unit, when they would like to accomplish it by, how they will accomplish their goal, and the estimated percentage of students that will reach this goal. This goal statement will then be presented to administrators, parents, and students in order to keep the teacher accountable to their plan.

\section{$\underline{\text { Discussion }}$}

Although educators cannot directly change the underlying factors leading to the achievement gap, they can take action to help the students overcome these limitations. So if it is so simple why has no one implemented this form of student support before? The simple answer is race. Although many people have access to the statistics about school districts, and specifically Portland Public School District, they choose to address things other than race as if to tip-toe around the subject. Portland is a very white city, leaving people of color in a very poor position. Although people will not directly say it, institutional racism is a large part in why nothing has been about the persistent gap in achievement.

\section{$\underline{\text { Conclusion }}$}

Many believe that it is the student's fault as to why they are not performing as well as their white peers, or it is the fault of the school they attend. In order for educators to truly help students overcome the achievement gap, they first need to evaluate how they may be contributing by not 
addressing the factors black students may face that white children may not. These students have entered a race to achieve success; the black students were put on a track with hurdles labeled neighborhood segregation, socioeconomic status, parent involvement, school discipline, and standardized tests. The white students have been given a free lane, clear of having to jump every one of the hurdles the black students have to face in order to succeed. Educators have to learn how to coach these students to help them jump these hurdles. The achievement gap has been argued about and discussed for many years, but this gap is not what needs to be addressed in order to solve the problem. The underlying factors that create hurdles for black students need to be brought to the forefront of education. These are the things that need to be discussed and addressed within the school system. Without removing these hurdles to the best of our abilities the race remains unfair, leaving black students further and further behind until they can no longer see the finish line of obtaining their educational success. 


\section{$\underline{\text { References: }}$}

Arcia, E. (2006). Achievement and enrollment status of suspended students outcomes in a large, multicultural school district. Education and Urban Society,38(3), 359-369.

Bates, L., \& Curry-Stevens, A. Coalition of Communities of Color (2014). The AfricanAmerican Community in Multnomah County: An Unsettling Profile.

Card, D., \& Rothstein, J. (2007). Racial segregation and the black-white test score gap. Journal of Public Economics, 91(11), 2158-2184.

Carter, P. L., \& Welner, K. G. (Eds.). (2013). Closing the opportunity gap: what America must do to give every child an even chance. Oxford University Press.

Diamond, J. B. (2006). Still separate and unequal: Examining race, opportunity, and school achievement in" integrated" suburbs. The Journal of Negro Education, 495-505.

Duncan, G. J., \& Magnuson, K. A. (2005). Can family socioeconomic resources account for racial and ethnic test score gaps?. The future of children, 15(1), 35-54.

Fan, X., \& Chen, M. (2001). Parental involvement and students' academic achievement: A metaanalysis. Educational psychology review, 13(1), 1-22.

Gibson, K., \& Abbott, C. (2002). Portland, Oregon. Cities, 19(6), 425-436. 
Gregory, A., Skiba, R. J., \& Noguera, P. A. (2010). The achievement gap and the discipline gap two sides of the same coin?. Educational Researcher,39(1), 59-68.

Kinsler, J. (2013). School discipline: A source or salve for the racial achievement gap?. International Economic Review, 54(1), 355-383.

Ladson-Billings, G. (2006). From the achievement gap to the education debt: Understanding achievement in US schools. Educational researcher, 35(7), 3-12.

Lee, J. (2002). Racial and ethnic achievement gap trends: Reversing the progress toward equity?. Educational researcher, 31(1), 3-12.

Oregon Department of Education (2012). Portland public school district report (2012). District Report Card for 2010-2011 School Year.

Orr, A. J. (2003). Black-white differences in achievement: The importance of wealth. Sociology of Education, 281-304.

Portland Public Schools (2010). Resolution No. 4326. Definition of High School System Design Principles.

Reardon, S. F., Valentino, R. A., Kalogrides, D., Shores, K. A., \& Greenberg, E. H. (2013). Patterns and trends in racial academic achievement gaps among states, 1999-2011. 
Stillwell, R., and Sable, J. (2013). Public school graduates and dropouts from the common core of data: School year 2009-10. U.S. Department of Education. Washington, DC: National Center for Education Statistics. Retrieved from http://nces.ed.gov/pubsearch

Steele, C. M., \& Aronson, J. (1995). Stereotype threat and the intellectual test performance of African Americans. Journal of personality and social psychology,69(5), 797. 